\title{
Visceral Effect of Female Genital Mutilation as Explained by Married People in Nigeria: Implications for Counselling
}

\author{
Umoh, S. H. ${ }^{1}{ }^{*}$, Adeoye, E. A. ${ }^{1}$, Bukoye, R.O. $^{2}$, Ogidan J. Rotimi ${ }^{3}$
}

(C) Uganda Martyrs University

\begin{abstract}
This study investigated the visceral effect of female genital mutilation as explained by married men and women in Nigeria. A Structured questionnaire designed by the researchers was administered to 500 respondents. Mean scores, Standard Deviation and Rank Order were used to analyse the responses collected. On the whole, the findings showed that women who were genitally mutilated faced several visceral effects after the surgical operation. These included self-reproach, poor self-image, painful menstrual periods and severe bleeding. Men whose partners were genitally mutilated confirmed that their wives faced these challenges. Based on these findings, it is recommended that counselling and education should be given to groups that still enforce this practice.
\end{abstract}

Keywords $\cdot$ Early Childhood Education $\cdot$ Management Strategies $\cdot$ Funding

\section{Introduction}

Female genital mutilation is defined by the World Health Organization (WHO), UNICEF and the United Nations Population Fund (UNFPA) (2006) as the partial or total removal of the female external genital or other injury to the female genital organs for cultural or other non-therapeutic reasons.

According to Apena (1996) female genital mutilation has been perceived as a barbarous, savage and injurious act that strips African women of their feminity, particularly their sexual sensitivity and pleasure. The practice of circumcision is primitive and barbaric, just as neonatal practice of removing earlobes, fingers or toes in some countries. This practice is a violation of women's human rights (Apena, 1996 and Mandara, 2000).

\footnotetext{
${ }^{1}$ University of Ilorin, *Corresponding author: umoharison@ unilorin.edu.ng 2 Ibrahim Badamasi Babangida University

3 National Open University of Nigeria
} 
World Health Organization (2005) also affirms that female genital mutilation is the procedure that involves partial or exclusive removal of the female external genital and/or injury to the female organs.

The mutilation most often performed is clitoridectomy or excision that is cutting off without anaesthetics, the clitoris and most of the external genitalia. According to Hosken (2003), female genital mutilation is practiced in abroad area from the Red sea to the Atlantic coast. Hosken emphasized that it is a most dangerous operation, infibulations or pharaonic circumcision. It is customary in Sudan, Somalia, Northern Kenya and parts of Mali and Nigeria; this practice is barbaric. Why it is regarded as barbaric was because after the clitoris is excised and all external genitalia are carved away, the bleeding raw edged of the large lips are held together by thorns or other fastening devices until a scar forms to close the entrance of the vagina. The legs of the female child are then tied together for several weeks until the wound heals; a tiny opening is created by inserting a splinter of wood to allow urination. Thus virginity which is considered especially important by Moslem and Christian men can be proven before the time of marriage.

Female genital mutilation in various forms is widespread in Nigeria. It ranges from amputation of the prepuce of clitoris to full infibulations. It also includes scarification of the genitals and cuts to the wall of the vagina. According to Mandara (2000) female genital mutilation (FGM) may be inflicted on children either at birth (Hausa) or on adult women (Yoruba) during pregnancy and before giving birth (Eastern Nigeria). In other countries where information are not available, women aged between 15 and 19 years are less likely to have been subjected to female genital mutilation (FGM) than are women in older age groups. The cut is usually carried out by Traditional Birth Attendants (TBAS) or barbers.

The reason given for subjecting the girl child and women to this hazardous operation include; enhancement of purity, prevention of prostitution, maintenance of differentiation between males and females and a sense of pride to female gender (Sotunde, 2006). From the point of view of Okpala (2000) female genital mutilation has a powerful impact on the psycho-sexual development and image of the little girl.

Khann (2001) mentioned that, the main reason why female genital mutilation (FGM) operation is performed on female gender was to enhance a husband's pleasure during the sex act. This is seen as, wickedness to women folk because it really means that only husbands or men should enjoy sexual, pleasure, leaving a woman in a state of emotional disequilibrium.

Despite all the efforts made by world leaders, and specifically the Nigerian government, to abolish the practice of female genital mutilation and possibly eradicate it completely, there has been a dramatic increase in the number of new FGM cases,

\section{Statement of the problem}

In 2006, UNICEF estimated that about $55 \%$ of Nigerian girls were mutilated genitally. Although this percentage is an underestimation, especially as those in the rural areas are usually not reported, it goes to show the enormity of the female genital problem in Nigeria. So one may then ask why civilized and educated parents still subject their own daughters to female genital mutilation. This is an issue that stakeholders should address for its total eradication.

Despite all the effort made by the world leaders specifically the Nigerian government to reduce the prevalence of female genital mutilation and if possible it's total eradication 
among the female gender; there has been a dramatic increase in the proportion of the operations. It is therefore against this backdrop that the need to investigate the opinion of both men and women in Nigeria on the effect of female genital mutilation on womenfolk becomes imperative.

In addition, in many communities in Kwara State such as Baruten, Kaiama, some parts of Ifelodun, Edu, Patigi, Asa, and Moro, including some States in Nigeria such as AkwaIbom, Edo, Cross-Rivers, Anambra, Borno, Osun, Ekiti, Benue to mention a few places, FGM is still being practiced. Majority (65\%) of female gender are subjected to FGM either before or after marriage without questioning (Maritz, 2005). This is a great violation to women human rights because apart from physical damage inflicted, it leaves life-long emotional scar and undermines women's self decision and sense of identity in the community where they belong. When compared with women who had not undergone genital mutilation, those mutilated run an enormous risk of going through caesarean operation, an episiotomy and an extended stay in hospital (Lancent, 2006).

Furthermore, women who are genitally mutilated suffer the problem of post partum haemorrhage, (Lancent 2006). Also, the infants of mothers who had undergone the more extensive form of the female genital mutilation are at an increased risk of dying at birth, compared with the infants of mothers without female genital mutilation. It could be observed here that the more extensive the genital mutilation, the higher the risk of obstetric complications.

\section{Purpose of the Study}

This study is aimed at identifying and highlighting the effects of female genital mutilation as explained by married men and women in Kwara State, Nigeria, so that its impact on the social and emotional stability of female gender might be identified, and in order that possible solutions and recommendations towards its total eradication in Nigeria might be proffered.

\section{Significance of the Study}

The study is very significant because the finding would enable parents to realize the havoc being done to the womenfolk, so that they can decide on the possible ways of eradicating the act. It will as well be of great help to other stakeholders (government, religious leaders, community leaders, among others) to know the serious health implications which female genital mutilation inflicts on the victims. This would gear up the government to sanction would- be perpetrators/offenders. The policy may also empower the female gender to reject FGM,

\section{Methodology}

The design employed for this study was a descriptive survey. The study was carried out in Kwara State, Nigeria, which has over two hundred and fifty different ethnic groups. The population for the study comprised genitally mutilated women and men whose wives were genitally mutilated from the 16 Local Government Areas of the State. Purposive sampling technique was employed to select the respondents from all the sixteen LGAs. The total number of 500 respondents was used; they included 300 genitally mutilated women and 200 men whose wives were genitally mutilated. The reason why women respondents were 
more than men respondents was just because genitally mutilated women are the main target.

In all, the women respondents comprised Yoruba, Hausa, Igbo, Nupe and other ethnic groups. All the 500 respondents who directly feel the effect of the mutilation or have a mutilated spouse responded to the copies of questionnaire given to them. The questionnaire was constructed by the researchers based on the review of related literature. To validate the instrument copies of it were given to three experts from the Health sciences, a consultant in gynaecology from the Teaching Hospital, and an official from the Ministry of Women Affairs, Ilorin, Kwara State, Nigeria. The necessary corrections were done and re-presented to the experts who adjudged that the instrument had content validity.

The reliability of the instrument was established through a split-half method. All the scores under both even and odd items were correlated using Pearson $\mathrm{R}$ techniques which gave 0.81 at 0.05 alpha levels.

The questionnaire was structured on a four point Likert type scale of Strongly Agree (S.A), Agree (A), Disagree (D), and Strongly Disagree (SD). It has a rating scale of 4, 3, 2, and I respectively.

Copies of the questionnaires were administered by the researchers through the research assistants who administered them in the 16 Local Government Areas. The respondents were allowed to fill the copies of the questionnaire at their convenience then return same through the researchers and their assistants. A $100 \%$ return of the competed copies was achieved. Mean scores were used to analyse the data collected.

\section{Scoring Procedure}

The maximum score on any of the positive response was 4 and the minimum score for the negative response was 1 . Hence the range for the mean score will be $(4+1) / 2$. The midpoint of the range was $5 / 2$ or 2.5 . Therefore, the cut-off point for determining whether the respondent perceived any of the items as the effect of FGM as high or low was 2.5. The visceral effect FGM value that equalled 2.5 or high was assumed to be high. However, any response that was less than this cut-off. (2.5) value was assumed to be low.

\section{Results}

The results are presented in the tables below in accordance with the respondents responses.

Table 1: Effects of FGM noted by Married Women

\begin{tabular}{llll}
\hline Attribute & Mean & SD & Rank \\
\hline Most genitally mutilated parts of the body take long time to heal. & 3.69 & 1.60 & $1 \mathrm{st}$ \\
Genital mutilation results in severe pain and bleeding. & 3.60 & 1.60 & $2 \mathrm{nd}$ \\
Women who undergo FGM experience painful menstrual periods & 3.56 & 1.55 & $3 \mathrm{rd}$ \\
Most women develop poor self-image after FGM operation & 3.41 & 2.45 & $4 \mathrm{th}$ \\
FGM is debasing and humiliating to womanhood. & 3.32 & 1.38 & $5 \mathrm{th}$ \\
FGM women are usually very unhappy about life situation & 3.15 & 1.17 & $6 \mathrm{th}$ \\
FGM women hardly feel comfortable in having sexual encounters & 3.14 & 1.40 & $7 \mathrm{th}$ \\
Genitally mutilated women find it hard to reach coital orgasm & 3.08 & 1.32 & $9^{\text {th }}$ \\
FGM increases the risk of contracting HIV and other STDs & 3.05 & 1.06 & $10 \mathrm{th}$ \\
Genitally mutilated women have poor in interpersonal skills & 2.70 & 1.04 & $12 \mathrm{th}$ \\
Genitally mutilated women are susceptible to prolonged labour & 2.25 & 1.03 & $16 \mathrm{th}$ \\
Genital mutilation accords respect to women folks & 2.20 & 1.05 & $17 \mathrm{th}$ \\
Genitally mutilated women often experience urine retention. & 1.20 & 0.67 & $20 \mathrm{th}$ \\
\hline
\end{tabular}


Table 1 indicates that women that are genitally mutilated actually experienced serious visceral effects as aftermath of the surgical operation. The level at which the FGM effects were ranked in order of the effects and the mean result ranging from 3.69 to 1.20 proved this.

Items 1, 2, 3, and 4 were seen as the visceral effect highly experienced by the respondents, while items $17,18,19$ and 20 were viewed as the visceral effect slightly experienced by the genitally mutilated females or women immediate attention to help female gender out of this menace is seriously needed.

Table 2: Effects of FGM noted by Married Men

\begin{tabular}{llll}
\hline Attributes & Mean & SD & Rank \\
\hline Husband of FGM victims find that their partners sexually boring & 3.40 & 2.31 & 1st \\
I notice FGM women do experience painful menstruation. & 3.20 & 2.19 & 2nd \\
Women who have undergone the surgery find sex irritable & 3.18 & 1.67 & 3rd \\
Genitally mutilated women are usually good home makers & 3.13 & 1.11 & 5 th \\
FGM women usually love their husbands. & 2.09 & 1.52 & 7 th \\
Genitally mutilated women are aggressive towards their children. & 2.00 & 1.20 & 8th \\
Genitally mutilated women are promiscuous & 1.33 & 1.37 & 9th \\
Genitally mutilated women are not likely to keep their homes. & 1.07 & 0.92 & 10th \\
\hline
\end{tabular}

Table 2 shows that, the married men, as well, indicated their concern and feelings about the visceral effects of FGM on genitally mutilated women in Nigeria. The level of their responses was revealed by the mean ranged from 3.40 to 1.07 and ranked from 1 st to 10 th in the same order. Items 1 to 3 show the stress the men have perceived in their genitally mutilated women. Such barbaric effect does not limit its effect on the spouses but also on the home and the children. Items 8,9 and 10 proved this. The situation of such has led to series of problems like separation, divorce, negligence, among others in many homes. Despite this, caring attitude and patience is needed by spouses of genitally mutilated women towards their wives to enhance harmonious families.

\section{Discussion}

The results of the study showed that women who are genitally mutilated actually face a lot of visceral effect after the surgical operation. This could be proved right from items I to 15 with mean mutilated part taking longer time to heal up. Severe bleeding are also common with their mean scores of 3.69, 3.60, 3.56, 3.01, and 2.53 respectively; and ranks as 1st, $2 \mathrm{nd}, 3 \mathrm{rd}, 11 \mathrm{th}$ and 14 th respectively. This is seen as wicked attitudes of the perpetrators to have carried out the operation without anaesthesia and having to stitch parts of vagina resulting in severe bleeding, pain, trauma and shock, hence prolonged labour and VVF. The findings support WHO (2000) where the artificial opening is too small for normal delivery. Prolonged labour results, which leads to damage of bladder and surrounding organs resulting in VVF. WHO (1995) also confirmed that, obstructed labour can lead to brain damage, urine retention or death.

The findings also revealed that genitally mutilated women suffer self-reproach, develop poor self-image, unhappiness about life situation, the women regarded the act as debasing and humiliating to womanhood, and suffering from traumatizing experiences with these respective mean scores: $3.41,2.51,3.15,3.32$ and 2.70 , ranked as 4th, 15th, 6th, 5th and 12th respectively. The reasons for these findings might result from sexual enjoyment the 
mutilated women were deprived of or stressful experiences associated with the environment where the mutilation took place and the attributed painful experiences during and after the mutilation. The findings were in support of Abogunrin (2001) who found that FGM operation may bring about excruciating pain on the girl/woman. In addition to causing intense pain, severe medical problems can arise which could lead to frustrating and inferiority complex on the mutilated women. It was also in support of study made by Abraham (2002) that uncircumcised women are more prone to psychological depression, feeling or reduced feminity and passive relationship with others, than uncircumcised ones, from the researcher point of view, the emotional impact of female genital mutilation is tremendous on the woman, and this could reflect on her relationship with people around hoi and with her spouse.

Another discovery made from the study was that, FGM women feel uncomfortable during sexual encounter, and as dangerous as the FGM is, it harbours a lot of genital sexually transmitted diseases (STDs) which may include HIV/AIDS thereby causing damage to the health of the woman. This could be confirmed in items 13 and 10 with mean scores of 2.64 and 3.32 respectively. These chronic visceral effects observed could result from the use of crude sharp and unsterilized instruments by traditional birth attendants (IBAs) like knives, pieces of glass, can opener, razor blade among others. This is in support of the study made by Abraham (2002) that circumcised women are more prone to psychological depression, feeling of reduced feminity and passive relationship with others, than uncircumcised ones. From the researchers' point of view, the emotional impact of female genital mutilation is tremendous on the woman, and this could reflect on her relationship with people around her and with her spouse.

These findings supported Robert (2000) discovery whose great concern is the possibility of spreading Human Immune Deficiency Virus (HIV) following the performance of mutilation. Robert noted that, the same unsterilized instrument could be used for as many victims there by encouraging the spread of AIDS and other virus that causes STDS. One can see at a glance from the study that, the practice is killing, is uncalled for and of no value to human existence. There is need for its total eradication.

Table2 reveals married men experiences about FGM. The men have confirmed that FGM women are passive on bed, experiences painful menstruations, and find sex irritable. Their husbands usually over labour to give them sexual enjoyment, some men also viewed that the anxiety of the surgery the; underwent does not allow them (mutilated woman) enjoy sex. The following mean scores 3.40, 3.20, 3.18 and 3.17 ranked 1st, 2nd, 3rd and 4th confirmed the findings. The reason for this might be due to the removal of clitoris, which had taken away the primary specialized female sex organ that increased sexual enjoyment. Also the inability of FGM women to reach orgasm might be due to the removal of closing up of sensitive tissues around the vagina. One could view from the findings that, when a husband is unable to get sexual satisfaction from his wife, there will be a strong urge for the man to look outside the matrimonial home for gratification of his sexual needs, which could lead to marital disharmony and eventually to separation and divorce. The finding was in support of Njelesani (2000) who emphasized that $50 \%$ of mutilated women studied had never experienced coital pleasure and they simply regarded the act as a duty. It is also in support of Jones (1999) who reported that $65 \%$ of such women never had orgasm and are indifferent to sexual encounter. The findings were contrary to the cultural beliefs and assertions that the female genitalia is dirty and that, when a woman's clitoris is removed, there will be reduction in virginal discharge. It is 
further asserted that it makes a woman look neat, enhance purity and increases her fertility (Njelesani, 1997). The finding was also in contrary to Tobias (1999) that FGM makes vaginal intercourse more desirable than clitoral stimulation. This confirms the predominant cultural beliefs in Nigeria that women are secondary citizens dominated by men; and who are just to be seen but not to be appreciated, and are created to make their husbands happy always.

From the findings, despite the negative effects experienced by some men from their vaginal mutilated wives, few men still have the view that FGM women are good home makers, and love their husbands. Items 5 end7 with mean scores \& 3.13 and 2.09 attested to this.

Findings supported the view of Rahman (2005) that the husbands of FGM women find pleasure with their wives because they are not promiscuous. Whatever happens however, FGM is a form of violence against women, which should not be tolerated under any circumstances.

\section{Implications for Counselling}

In Nigeria, children are brought up to unquestionably obey their parents, other senior members of the family, extended family members or clan members. Moreover, to be accepted by parents, relatives, ethnic group members, an individual must be seen to be dependent and unable to make Independent decision. It is very important to note that there are some unreasonable harmful traditional belief and practice, which are passed on to children as they grow up for the continuity of the culture. Female genital mutilation Is one of such; because despite the serious harmful effect the practice brought on women folks; many parents especially some women still support the infliction of the practice on their female-child. Counselling being a helping relationship designed to help individual live a balanced, adjusted, fulfilled meaningful and happy life can play important roles in curbing or controlling' the unreasonable practice through reasoning. There is need for the intervention of health counsellors and professional counsellors to rise up towards immediate eradication of this harmful practice. The counsellors are advised, first of all, study and understand the motives behind the custom before convincing resolution to stop the practice is provided.

The intervention by the counsellor does not mean total condemnation of the practitioners because they see the practice as their source of income but rather, they should be made to understand the havoc the practice is causing to women reproductive health and emotional condition. Also, through counselling the practitioners should be made to realize the danger associated with the cutting of female genitalia.

Counselling activities must be carried to the grassroots level where the practice is most common and counsellors in various states should emphasize on the harm and havoc FGM cause to women folk and needs for its eradication. At the grassroots level, series of plays and drama can be staged to illustrate the effects and to promote its eradication among rural dwellers. At such level and to other citizenry, series of deadly diseases and infections associated with the use of crude instruments should be mentioned and the need to seek the need of medical experts should be emphasized.

Women who have already fallen victims of FGM must be counselled against involving their daughters in the practice. Efforts should be made to discourage the public against the cultural belief that they have imbibed in their minds. Counselling theories like Rational 
Emotive Therapy and Reality therapy must be effectively utilized to give positive reasoning towards putting an end to the practice. Government should enact a strong policy towards the stopping of FGM and anybody who deviates should be punished severely. The government, and philanthropists, should also sponsor jingles, plays and other activities that campaign against FGM practice and illustrate punishments that can be discharged to its perpetrators. This could be done on the Television, Radio, and in dailies. Seminars, workshops and enlightenment campaigns against FGM should also be launched for the parents, youths, religious leaders and community leaders among others. These activities should be implemented in a way that they reach the grassroots level. Health officials should also be assigned to monitor the practice in their areas of operation and discourage people from perpetrating it. Inter-agency teams that bring together representatives of various government ministries, NGOs professional organization and association fighting FGM should also be established to ensure stronger action against FGM.

\section{References}

Abogunrin, A.J. (2001) Female Genital Mutilation and Its Effluence on family life: Implications for counselling. Unpublished Ph.D. Project.

Abraham, E. K. (2002) Infibulations: Female Mutilation in Islam in North Eastern Africa. New Brunswick. New Jersey: Transaction pub.

Moritz, S. (2005) Post-traumatic stress disorder and memory problems after female Genital mutilation. American Journal of Psychiatry 162; 1000-02.

Apena, A. (1996), Female Circumcision in Africa and the Problem of Cross-cultural perspectives.

Hosken, F. P. (2003), Genital and Sexual Mutilation of females. Lexington: Women international.

Jones, H. (1999) Female Genital Cuffing Practices in Burkina Faso and Mali and their negative health outcomes. Studies in Family Planning 30(3) 219 - 220.

Lancet, W. (2006) Female Genital Mutilation: A Cultural Legacy of Pain. The Health Exchange.

Khann, A. T. (2001) Female Circumcision: Tropical Doctor. A Journal of Modem Medical Practice. 1 (5).

Mandara, E. (2001) Reality Therapy: A raw approach to psychiatry. New York: Harper and Row.

Njelesani, E. (1997) Circumcision is responsible for high maternal mortality, health. The Guardian, P. 35.

Okpala, N. (2000) Female Circumcision as a public health issue. New England Journal of Medicine. 716.

Rahman, A. (2005) Female Genital Mutilation: A guide to laws and policies Worldwide. London; Zed Books.

Sotunde, O.A. (2006) Female Circumcision and Marital Stability among Women in Ibadan, Oyo state.

Tobias, N. (1999) Genital Mutilation: A call for Global Action. NY. UNFPA.

UNFPA (2006) Female Genital Mutilation: A joint statement Geneva: Author.

WHO (1995), Female Genital Mutilation. Report of a WHO Technical working Group Geneva: Author. 
WHO (2005) Female Circumcision: A traditional practice that threatens health. WHO Chronicle: Author.

WHO (2005) Report of the female genital mutilation Technical Working group. Geneva, $17-19$. 